\title{
Studies Regarding the Efficiency of Grape Tannins Greening Plastics
}

\author{
GABRIELA IGNAT ${ }^{1}$, CINTIA COLIBABA ${ }^{1 *}$, CARMEN LUIZA COSTULEANU ${ }^{1}$, IOAN MORARU ${ }^{1}$, CATALIN RAZVAN VINTU², \\ GEORGE UNGUREANU ${ }^{3}$, COSTICA BEJ INARIU4,5* \\ ${ }^{1}$ Ion Ionescu de la Brad University of Agricultural Sciences and Veterinary Medicine of Iasi, 3 M. Sadoveanu Alley, 700490, Iasi, \\ Romania \\ 2 University of Agronomic Sciences and Veterinary Medicine of Bucharest, 59 Marasti Blvd, 011464 Bucharest, Romania \\ ${ }^{3}$ University of Agronomic Sciences and Veterinary Medicine of lasi, 3 Mihail Sadoveanu Alley, 700490, Iasi, Romania \\ ${ }^{4}$ Romanian Inventors Forum, 3 Sf. Petru Movila Str., 700089 Iasi, Romania \\ ${ }^{5}$ Gheorghe Asachi Techical University of lasi, Faculty of Science and Engineering Materials, 67 Dumitru Mangeron Str., 700050 \\ lasi, Romania
}

\begin{abstract}
Grape marc, also known as grape pomace, is one of the most investigated bio-wastes derived mainly from grape skin and seeds, which is produced as a by-product of winemaking on the million-ton scale annually. Presently, the most important high-value use of grape pomace is in the production of oenological tannins, widely-used additives in the food and beverage industry. This article studies the possible use of grape waste in the plastic industry, as request of the consumer for green plastics with regards to environmental impact, and in the case of packaging, to improve the shelf-life and safety of the products contained. 4 white grape varieties and 4 red grape varieties (most cultivated grape varieties in Romania) were taken into study, processed using different technological methods and the spent material (grape skins and seeds) were analysed regarding their total phenolic compounds and total tannins.
\end{abstract}

Keywords: grape marc, oenological tannins, polymers, food and beverage industry

The grape and wine industry produces a readily available agro-waste, which is high in antioxidant compounds [1-2-3].The antioxidant activity associated with grape extracts is linked to the polyphenolic compounds contained, including benzoic acids, hydroxycinnamic acids, flavan-3-ols, and flavones. The individual phenolic compounds extracted and isolated from this waste stream have been shown to be high in antioxidant activity [4 - 5]. Grape tannins involve higher molecular weight polyphenol compounds found in the skins and seeds of grapes. As grape tannins are extracted from a natural food source, they are generally regarded as safe, which allows for their use in contact with foods.

Natural antioxidants have taken an important role as additives within polymers. The stability, oxidative induction time, thermal degradation, antioxidant capacity and plasticizing affects have been considered for grape extracts, green tea extracts, tomato waste, seaweeds, fish proteins, mortal leaves, essential oils of herbs, and other natural extracts. These have been included in a variety of materials: polyolefin's, such as polypropylene [6-8] ultra-high molecular weight polyethylene [9], natural polymers, such as chitosan [1012], cellulose [12], and others [13, 14]. These studies have shown the diversity of natural components that can be incorporated or made into films to produce materials suitable for various applications.

Current studies examine the role of multiple isolated components [15], but research on antioxidant activity has mainly cantered on individual compounds isolated from natural sources and incorporated into films [1520].

Cellulose polymers have many applications and are capable of meeting the natural and green demands of consumers. Integration of natural extracts has been shown to enhance the properties of these polymers [ 12 , 19].

\footnotetext{
*email; cintia_colibaba@yahoo.co.uk; costica.bejinariu@yahoo.com
}

This study wants to bring some light onto the possibility of using sub products of wine-making in the plastic industry, while analysing eight of the most widely spread Romanian grape varieties and different methods of winemaking, all influencing the content of total tannins and total polyphenolic compounds.

\section{Experimental part}

Material and methods

The used grape varieties are as follows: Feteasca regala - Fr, Feteasca alba - Fa, Chardonnay - Ch, Sauvignon blanc - Sb, Babeasca neagra - Bn, Feteasca neagra - Fn, Cabernet Sauvignon - CS, Merlot - M. These were harvested in 2011 from V. Adamachi farm of the USAMV lasi. The grapes were processed as follows [21]:

- for white wines ( $\mathbf{p}$ - prefermentative and $\mathbf{c}$ - classical variant);

- for red wines (c - classical maceration, $\mathbf{r}$ - rototanks maceration, $\mathbf{t}$ - thermo maceration, $\mathbf{m}$ - microwave maceration).

The pomaces were hand-sorted, freeze-dried, and ground using a micro-mill (Kika Werke M20). $10 \mathrm{~g}$ of ground sample was mixed with $40 \mathrm{~mL}$ of solvent, concentrated by a Heidolph Laborota 4003 rot evaporator, brought to 50 $\mathrm{mL}$ with methanol prior to analyses.

Total polyphenolic index or D280 index describes the content of phenolic compounds in wines. Total tannins (methylcellulose index) - according to AWRI standard methods, 2007.

\section{Results and discussions}

The phenolic compounds in waste grape material are expressed in milligrams equivalent galic acid.gram skins or seeds (mg EAG/g).

Total phenolic compounds of waste grape material (skins) in white wines are presented in figure 1. As expected, the values are low, polyphenols being in much smaller quantities in white wines (the lowest value is 


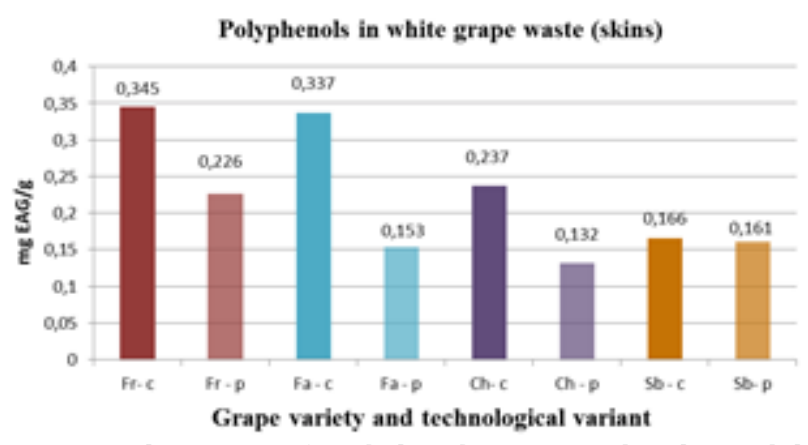

Fig. 1. The content of total phenolic compounds exhausted the material (skins) of white wines obtained in 2011

registered in the case of Feteascã albã prefermentative maceration variant while the highest is in the case of Feteascã regalã classical maceration variant). The prefermentative variants all have lower values than the classical ones, as the phenolic compounds, during maceration, have diffused in the must.

Figure 2 presents data concerning the total phenolic compounds of waste grape material (skins) in red wines. The highest value is registered in the case of Babeasca neagrã thermo maceration variant, while the lowest is in the case of Merlot classical maceration. Of course, the applied heat maceration methods increase the values.

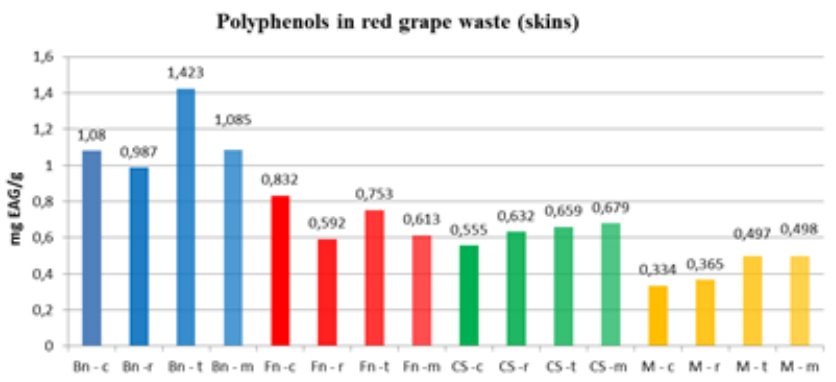

Grape variety and technological variant

Fig. 2. The content of total phenolic compounds of depleted material (skins) of red wines obtained in 2011

The total phenolic compounds of waste grape material (seeds) in white wines can be seen in figure 3 . The highest index is in the case of Chardonnay seeds from the waste grape material, while the lowest is in the case of seeds of Feteasca regala prefermentative maceration. The prefermentative variants all have lower values than the classical ones, as the phenolic compounds, during maceration, have diffused in the must.

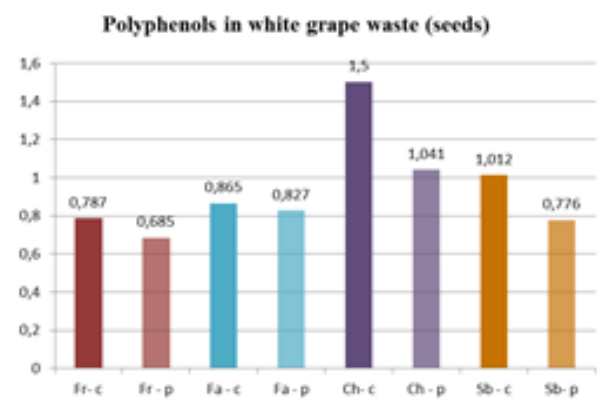

Grape variety and technological variant

Fig.3. The content of total phenolic compounds of depleted material (seeds) of white wines obtained in 2011

The total phenolic compounds of waste grape material (seeds) in red wines can be seen in figure 4. Babeasca neagra classical maceration seeds from the waste grape material registered the highest values in the case of phenolic compounds. Feteasca neagrãa microwave maceration had the lowest values, in this case.
Polyphenols in grape waste (seeds)

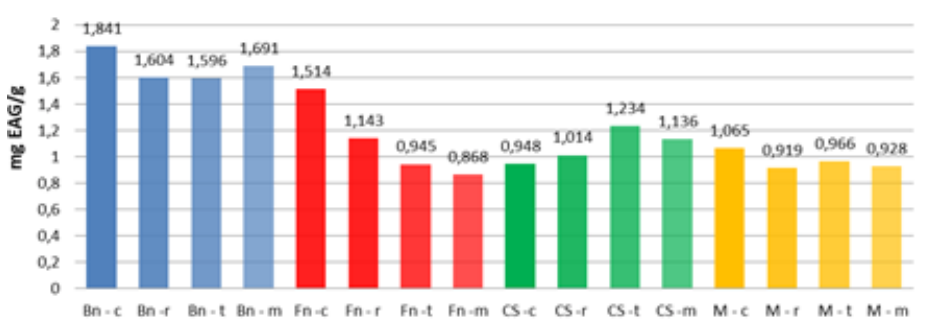

Grape variety and technological variant

Fig. 4. The content of total phenolic compounds of depleted material (seeds)

Figure 5 presents data regarding the values of the methylcellulose index of waste grape material (skins) of white wines. The highest value is registered in the case of Feteasca regala classical maceration, the lowest in the case of Chardonnay prefermentative maceration. The values corresponding to prefermentative variants are lower than those of the variants obtained by classical maceration, as the seeds loose tannins during their contact the must. The values of the index for the spent material of the local Feteascã regalã and Feteasca alba wines are higher than those of Sauvignon blanc and Chardonnay.

Tannins in white grape waste (skins)

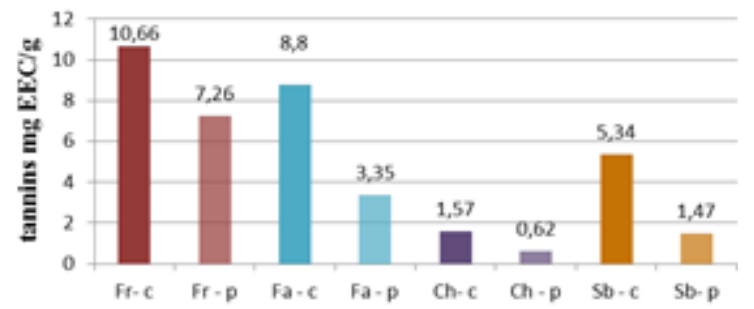

Grape variety and technological variant

Fig. 5. Total tannin content of exhausted material (skin) of white wines produced in 2011

Figure 6 presents data regarding the values of the methylcellulose index of waste grape material (skins) of red wines. The highest value is in the case of the Cabernet sauvignon thermo maceration variant. The lowest value is registered in the case of Feteascã neagra classical maceration.

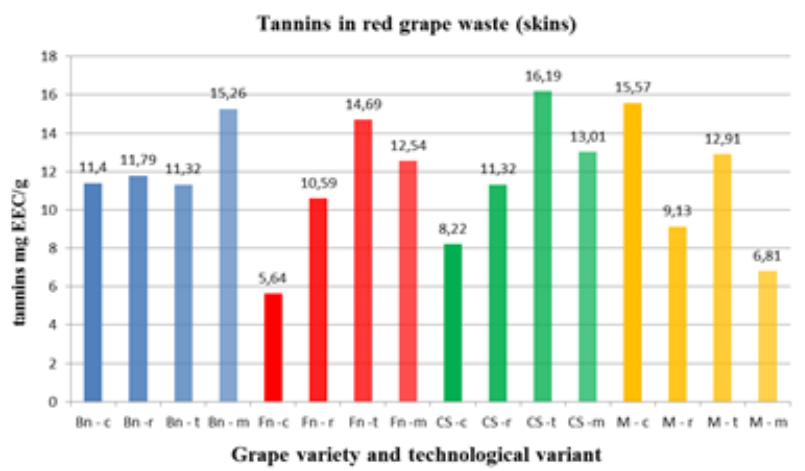

Fig. 6. Total tannin content of exhausted material (skins) of red wines produced in 2011

Figure 7 represents the values of the methylcellulose index in grape waste (seeds) of white varieties. The highest and the lowest index is registered in the case of Chardonnay seeds, where classical and preferementative maceration are applied. Again, the values corresponding to prefermentative variant are lower than those of the variants obtained by classical maceration, due to the time 


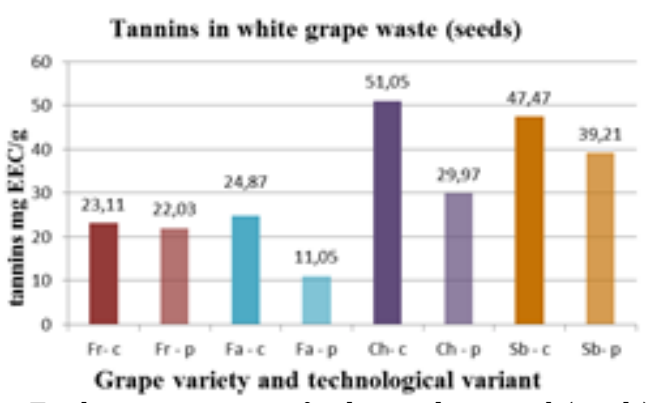

Fig. 7. Total tannin content of exhausted material (seeds) of white wines produced in 2011

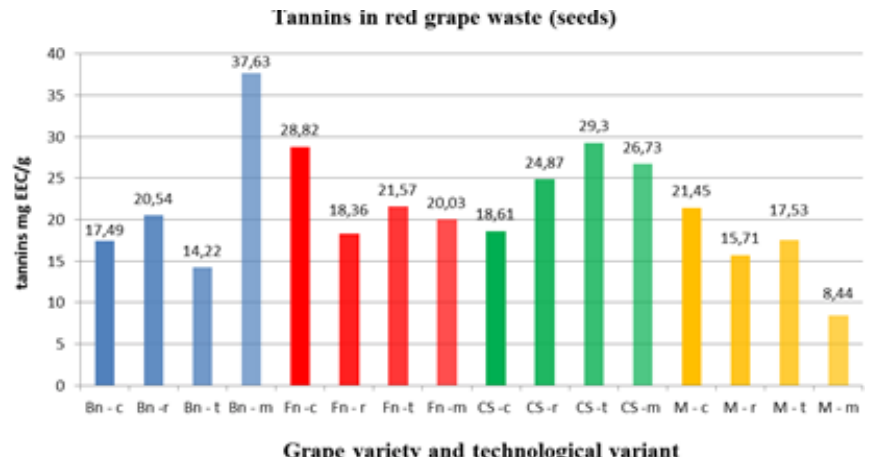

Fig. 8. Total tannin content of exhausted material (seeds) of red wines produced in 2011

the seeds spend in direct contact with the must. The international grape varieties have much higher values than the Feteasca varieties.

Figure 8 presents data regarding the methylcellulose index of grape waste (seeds) from red wines. The highest is found in the case of the seeds of Bãbeascã neagrã grape variety, where microwave maceration was applied. The lowest is registered in the case of Merlotseeds, microwave maceration.

\section{Conclusions}

The present study presents the possibilities of using waste from the winery (seeds and skins of grapes, after pressing) for their polyphenols and tannins' content in the plastic industry domain. The high number of grape varieties used, both local and international grapes, create a complex background, for researchers to choose from. The values of the TPI and the total tannin content vary according to grape variety but also the maceration technology used. Local grape varieties (Babeascã neagra - tannins in seeds and seeds and Feteascã regalã - tannins in skins and seeds) have great potential for extracting polyphenols and tannins from grape waste; however, further research is needed in order to identify the best methodologies for this matter. At the current time, a heat aided maceration seems to be the best choice; how ever, the economic viability of these technologies is to be studied further.

\section{References}

1.ALIAKBARIAN, B., FATHI, A., PEREGO, P., DEHGHANI, F., J ournal of Supercritical Fluids, 65, 2012, p.18.

2.ARVANITOYANNIS, S., LADAS, D., MAVROMATIS, A., International Journal of Food Science \& Technology, 41, 2006, p. 475.

3.FONTANA, A.R., ANTONIOLLI, A, BOTTINI, R., Journal of Agricultural and Food Chemistry, 61, 2013, p. 8987.
4.DE CAMPOS, LMAS., LEIMANN, F., PEDROSA, R., FERREIRA, S., Bio resource Technology, 99, 2008, p. 8413.

5.LAFKA, T., SINANOGLOU, V., LAZOS, E., Food Chemistry, 104, 2007, p. 1206.

6.AMBROGI, V., CERRUTI, P., CARFAGNA., C, MALINCONICO, M., MARTURANO, V., PERROTTI, M., PERSICO, P., Polymer Degradation and Stability, 9, 2011, p. 2152.

7.CERRUTI, P., MALINCONICO, M., RYCHLY, J., MATISOVA-RYCHLA, L., CARFAGNA, C., Polymer Degradation and Stability, 94, 2009, p. 2095.

8.NERIN, C., TOVAR, L., DJ ENANE, D., CAMO, J., SALAFRANCA, J., BELTRÁN, J., RONCALÉS, P., Journal of Agricultural and Food Chemistry, 54, 2006. p. 7840.

9.PELTZER, M., WAGNER, JR., J IMENEZ, A., Journal of Thermal Analysis and Calorimetry, 87, 2007, p. 493.

10. MORADI, M., TAJIK, H., RAZAVI, ROHANI, SM., OROMIEHIE, AR., MALEKINEJ AD, H., ALIAKBARLU, J., HADIAN, M., J ournal LWTFood Science and Technology, 46, 2012, p. 477.

11.RUBILAR, JF., CRUZ, RMS., KHMELINSKII, I., VIEIRA, MC., International J ournal of Food Studies 2, 2013, p. 22.

12.KRIZOVA, H., WIENER, J., Autex Research J ournal, 13, 2013,

p. 33.

13.CERRUTI, P., SANTAGATA, G., GOMEZ D'AYALA, G., AMBROGI,

V., CARFAGNA, C., MALINCONICO, M., PERSICO, P., Polymer Degradation and Stability, 96, 2011, p. 839.

14. LI, J-H., MIAO, J, WU, J-L., CHEN, S-F., ZHANG, Q-Q., Food Hydrocolloids J ournals 37, 2014, p. 166.

15. SILVA-WEISS, A., IHL, M., SOBRAL, PJA., GÓMEZ-GUILLÉN, MC., BIFANI, V., Food Engineering Reviews, 5, 2013, p. 200.

16. ARRUA RD, BASBUS J F, STRUMIA MC, ALVAREZ IGARZABAL Cl, NAZARENO MA J ournal Reactive and Functional Polymers, 72, 2012, p. 807.

17. HELAL, A., TAGLIAZUCCHI, D., CONTE, A., DESOBRY, S., International Dairy J ournal, 25, 2012, p. 10.

18. IÑIGUEZ-FRANCO F, SOTO-VALDEZ H, PERALTA E, AYALAZAVALA JF, AURAS R, GÁMEZ-MEZA N., J ournal of Agricultural and Food Chemistry, 60, 2012, p. 6515.

19. PASTOR C, SANCHEZ-GONZALEZ L, CHIRALT A, CHAFER M, GONZALEZ-MARTINEZ C., Food Hydrocolloids Journals, 30, 2013, p. 272.

20. SPIZZIRRI, UG., IEMMA, F., PUOCI, F., CIRILLO, G., CURCIO, M., PARISI, OI., PICCI, N., Biomacromolecules J ournals, 10, 2009, p. 1923.

21. MORARU, I., PhD Thesis, USAMV Iasi, 2014.

22.BRAHMA, J., BRAHMA, B.K., International J ournal of Conservation Science, 7, no. 1, 2016, p. 137.

23. ANTOCE, A., Rev. Chim. (Bucharest), 63, no. 9, 2012, p.859.

24. BUZAS, M.C., CHIRA, N., DELEANU, C., ROSCA, S., Rev. Chim. (Bucharest), 54, no. 10, 2003, p. 831.

25. HANGANU, A., TODASCA, M.C., MANOLACHE, F.A., ROSCA ,S., Rev. Chim. (Bucharest), 63, no. 3, 2012, p. 243.

26. SCHMUTZER, G., AVRAM,V., COMAN, V., LEONTIN, D., MOLDOVAN, Z., Rev. Chim. (Bucharest), 63, no. 9, 2012, p.855.

27.IGNAT, G., BALAN, G., SANDU, I., COSTULEANU, C.L., TUDOSE SANDU VILLE, S., Rev. Chim. (Bucharest), 67, no. 8, 2016, p.1560.

28.GARLEA, A., MELNIG, V., POPA, M.I., RUSU, G., Mat. Plast., 45, no. 2, 2008, p. 193.

29.GEORGESCU, M., SACA, N., MINCU, G., Rev. Chim. (Bucharest), 59, no. 8, 2008, p. 842.

30.ORBAN, H., CIRSTOIU, C., ZAHARIA, C., CIUCU, C., Rev. Chim. (Bucharest), 59, no. 6, 2008, p. 688.

Manuscript received: 18.02 .2017 